http://jmscr.igmpublication.org/home/ ISSN (e)-2347-176x ISSN (p) 2455-0450 crossref DOI: https://dx.doi.org/10.18535/jmscr/v8i3.51

\title{
Knowledge and Attitude towards Organ Donation among Medical Students of a Government Medical College in Northern Kerala
}

\author{
Authors \\ Dr Akhila Jose ${ }^{1}$, Mrs. Mayamol T R $\mathbf{R}^{2}$, Dr Jayasree A K \\ ${ }^{1}$ House surgeon, Govt. Medical College, Kannur, Kerala \\ ${ }^{2}$ Asst. Professor, Dept of Community Medicine, Govt. Medical College, Kannur, Kerala \\ ${ }^{3}$ Head of the Department, Department of Community Medicine, Govt. Medical College, Kannur, Kerala \\ *Corresponding Author \\ Mrs. Mayamol T R \\ Asst. Professor, Department of Community Medicine, Government Medical College, Kannur, Kerala
}

\begin{abstract}
Background: With newer technologies in modern medical practice, organ harvesting and organ transplantation have given many patients with organ failure a renewed lease of life. But the demand for organs for transplantation continues to vastly surpass the inadequate supply capacity all over the world. In India, organ donation from brain death is mere $0.16 \%$ per million populations as compared to 32 in Spain, 22 in US and 14 in UK. Health care professionals are the key link in organ donation process in motivating, educating and allaying the fear of public about this. Hence it is important to emphasize the knowledge and attitude of the medical students who are the future hopes of improving the poor scenario in our society.

Materials and Methods: A cross sectional study was conducted among MBBS students (first, second and third year) of Government Medical College, Kannur after obtaining institutional ethical clearance and data was collected by pre tested self-administered questionnaire. The study was conducted in September, 2017.

Sample size of 100 were selected by convenient sampling and those students who were present and gave consent were included in the study.

Results: Out of 100 participants 75 were females and 25 males. 98\% of them were aware of organ donation and $92 \%$ about organ donation after brain death also. Regarding the various organs which can be transplanted $53 \%$ had very good knowledge .71\% are aware of the most commonly donated organ $73 \%$ are correct in their choice about the ideal candidate for organ donation. $86 \%$ are in favour of including education about organ donation as part of medical curriculum. The important observation is $81 \%$ of them expressed willingness to organ donation.

Conclusion: Most of the medical students had good knowledge regarding organ donation and are willing to donate. But only half of them have correct knowledge regarding which all organs can be donated.
\end{abstract}

\section{Introduction}

Organ transplantation is the key medical procedure in end stage organ failures that saves many lives. The evolution of advanced technologies in the scientific world have made organ harvesting for organ transplantation a safe and viable procedure for prolonging the lives of people suffering with organ failure. Organ 
donation is defined as the removal of tissues from the human body, from a living or dead person, for the purpose of transplantation as a treatment ${ }^{1}$.

Despite India being the world's second-most populous country, it has a pathetic deceased organ donation rate of just $\mathbf{0 . 2 6}$ per million population compared to 26 in the US, 35 in Spain and 36.5 in Croatia. The Ministry of Health \& Family Welfare had launched the 6th world and first-ever Indian Organ Donation Day and Organ Donation Congress in 2010 in New Delhi ${ }^{2}$. There is a worldwide shortage of donor organs in comparison to the need for transplantation.

A wide gap exists between patients who need transplants and the organs that are available in India. An estimated around 1.8 lakh persons suffer from renal failure every year, however the number of renal transplants done is around 6000 only. An estimated 2 lakh patients die of liver failure or liver cancer annually in India, about $10-15 \%$ of which can be saved with a timely liver transplant. Hence about 25-30 thousand liver transplants are needed annually in India but only about one thousand five hundred are being performed. Similarly about 50000 persons suffer from Heart failure annually but only about 10 to 15 heart transplants are performed every year in India. In case of Cornea, about 25000 transplants are done every year against a requirement of $1 \mathrm{lakh}^{3}$.

The shortage in organ supply is due to lack of awareness and correct knowledge among public, myths and misconceptions surrounding organ donation due to religious and cultural barriers leading to hesitancy in donation of human organs ${ }^{4}$. It has also been identified as due to the reluctance of family members to donate due to fear of the surgery causing loss to their health, smaller nuclear families with unmatchable donors and a deceased donor program that is still evolving.

Organ donation is the process when a person allows an organ of their own to be removed and transplanted to another person, legally, either by consent while donor is alive or dead with the assent of the next of kin. Organs can be donated after brain death. Heart, Kidney, Lungs, Liver,
Skin, Cornea are common organs donated and Kidney is the most common. There is a time for which organs remain viable and the basic screening tests are blood investigations, HLA typing, blood grouping. Cancer and HIV are absolute contraindications for organ donation. There is no age limit for organ donation. Siblings are ideal candidates. Transplantation of human Organs Act was enacted in 1994 .There is a shortage of organs in India for transplantation. None has to pay to be an organ donor. ${ }^{1,2,3,4,5,6}$

There is a significant relation between public attitude towards organ donation and availability of such organs. Thus the main concern of most transplant surgeons is to increase the donor pool and spread the willingness of donation among healthy individuals. Knowledge and attitude of health care providers towards organ donation plays a major role in promoting the concept among population. A better understanding of the barriers, facilitators and opportunities for organ donation and transplantation is needed in India. As future medical practitioners an assessment of knowledge and attitude of medical students towards organ donation in the budding stage is very much significant.

In this study knowledge and attitude of undergraduate students of Government Medical College, Kannur were assessed. The objectives of this study were to understand the awareness and knowledge of medical students about organ donation and to assess the attitude of medical students towards organ donation.

\section{Materials and Methods}

The study was conducted among first, second and third year MBBS students of Government Medical College, Kannur. Institutional ethical clearance was obtained. It was a cross-sectional study and the data was collected by pre tested selfadministered questionnaire. Sample size of 100 were selected by convenient sampling method. The questionnaire had three sections. The first was about the demographic details like age, sex, religion and year of study. The second section 
consisted of questions to assess the knowledge of students regarding organ donation. The third section comprised of questions to assess the attitude of medical students towards organ donation. Correlation between knowledge and attitude of students towards organ donation has been assessed.

\section{Results}

Out of the 100 medical students who participated in the study 36 were first year students, 29 were second year students and 35 were third year medical students. Mean age of students participated is 20.92.32 were in age group 1819,40 were in $20-21$ and 28 in $22-23$ years. 25 were males and 75 females.60 were Hindus, 26 were Christians and 14 were Muslims. The sociodemographic profile of participants is given in table 1.

Table.1

\begin{tabular}{|l|l|}
\hline AGE GROUP & 32 \\
18-19 years & 40 \\
$20-21$ years & 28 \\
22-23 years & \\
\hline SEX & 25 \\
Male & 75 \\
Female & \\
\hline RELIGION & 60 \\
Hindu & 26 \\
Christian & 14 \\
Muslim & \\
\hline
\end{tabular}

Table no:2 Response of participants towards knowledge and attitude questions

\begin{tabular}{|l|c|c|c|}
\hline & Yes & No & Don't Know \\
\hline 1.Can organs be donated when alive? & 96 & 2 & 2 \\
\hline 2.Can organs be donated after brain death? & 92 & 5 & 3 \\
\hline 3.Is there any age limit for organ donation? & 42 & 32 & 26 \\
\hline 4.Have you heard of transplantation of human organs act? & 42 & 39 & 19 \\
\hline 5.Is there any shortage of organs in India? & 73 & 9 & 18 \\
\hline 6.Do you have to pay for being an organ donor? & 12 & 77 & 11 \\
\hline 7.Can anyone accept money for donating organ? & 46 & 38 & 16 \\
\hline 8.Do you feel organs can be misused or abused? & 52 & 34 & 13 \\
\hline
\end{tabular}

Assessment of knowledge of medical students about organ donation: There were 13 questions included to assess the knowledge. Out of 100 participants 98 said that organs can be donated when alive. $92 \%$ said organs can be donated after brain death. $5 \%$ said organs can't be donated after brain death and $3 \%$ of them marked the doesn't know option. Regarding which all organs can be donated, scoring of 5-6 were under very good knowledge, 3-4 good knowledge,0-2 under poor knowledge. Also regarding absolute contraindications of organ donation those who made all options correct were considered as having very good knowledge, who made atleast one correct having good knowledge and made both incorrect are considered to be having poor knowledge. The legal aspects were also included $53 \%$ of them had very good knowledge about which all organs can be donated,47\% had good knowledge. Regarding the most common organ donated $71 \%$ gave correct answer ie; Kidney, 27 $\%$ made wrong and $2 \%$ of them didn't marked an answer. $89 \%$ said there is a time duration for which organ remain viable. $3 \%$ said there is no such time duration and 8 of them doesn't know about it. $42 \%$ said there is age limit for organ donation, $32 \%$ said there is no such age limit,26\% doesn't know about the age limit. Regarding the screening tests for organ donation $75 \%$ gave correct answer, 23\% made wrong and 2\% didn't attend the question. $28 \%$ had very good knowledge about absolute contraindication $64 \%$ had good knowledge and 8 had poor knowledge. Only $42 \%$ of them have heard of transplantation of human organs Act, and $11 \%$ gave correct answer for year in which law was enacted. $73 \%$ of them answered the siblings are the ideal candidates for organ donation. $31 \%$ had sufficient source of information from newspaper, magazines, tv, internet, friends. From the various 
sources of information those with 4-6 sources were considered as sufficient,2-3 as good and 0-2 as poor.. The various sources of information regarding organ donation among the participants are depicted in Figure1. $73 \%$ were aware that there is shortage of organs for transplantation in India.12\% said that they have to pay to be an organ donor, $77 \%$ were aware that they need not pay to be an organ donor.

Figure 1 Sources of information regarding organ donation

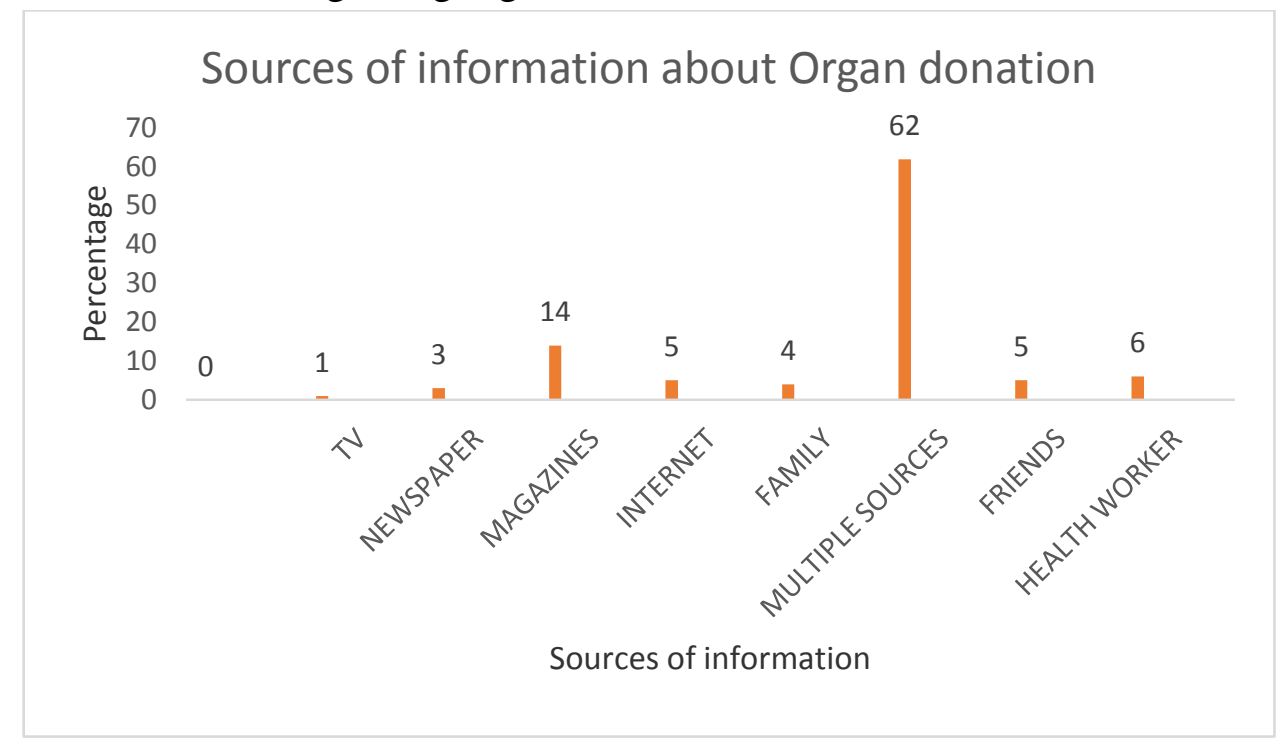

Figure No:2 Assessment of knowledge trend and year of study among medical students

\section{Satisfactory knowledge about organ donation among medical students}

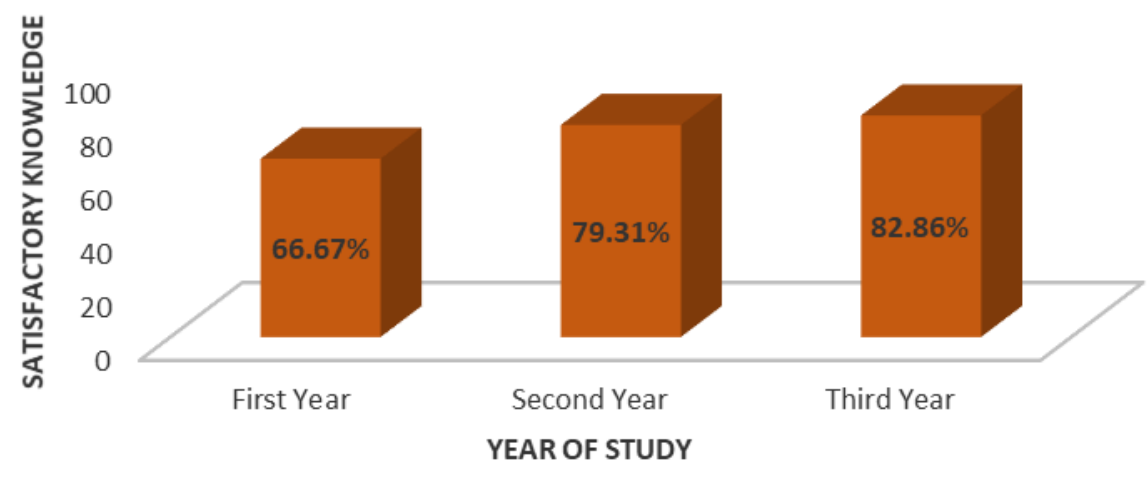

Assessment of attitude of medical students towards organ donation:

90\% of the students are in favor of the concept of organ donation, $7 \%$ were not and 3 didn't gave a response. $52 \%$ opined that identity of donor should be revealed to recipient , $48 \%$ were against. $52 \%$ said that there can be misuse of organs, $86 \%$ said that awareness about organ donation should be included in medical curriculum.
Willingness towards organ donation

$81 \%$ were willing for organ donation. $19 \%$ were not willing. Among the reasons for not willing for organ donation $7 \%$ gave dislike for separation of organs from body, religious restrictions-1\%, objections from family-5\% and other reasons- $6 \%$. Among the various religions, willingness to donate organs is given in Table 3. 
Table 3

\begin{tabular}{|l|c|c|c|c|}
\hline RELIGION & & Yes & No & Total \\
\hline Hindu & Number & 51 & 9 & 60 \\
& Percentage & $85 \%$ & $15 \%$ & $100 \%$ \\
\hline Christian & Number & 21 & 5 & 26 \\
& Percentage & $80.8 \%$ & $19.2 \%$ & $100 \%$ \\
\hline Muslim & Number & 9 & 5 & 14 \\
& Percentage & $64.3 \%$ & $35.7 \%$ & $100 \%$ \\
\hline
\end{tabular}

The association between knowledge and attitude of medical students towards organ donation is given in Table 4.

Table No. 4.

\begin{tabular}{|c|c|c|c|c|}
\hline $\begin{array}{l}\text { Attitude } \\
\text { group }\end{array}$ & & Satisfactory Knowledge & $\begin{array}{l}\text { Unsatisfactory } \\
\text { Knowledge }\end{array}$ & Total \\
\hline Negative & $\begin{array}{c}\text { Count } 7777 \\
\% \text { within attitude group } \\
\% \text { within knowledge group }\end{array}$ & $\begin{array}{c}7 \\
50 \\
29.17 \\
777 \\
7750\end{array}$ & $\begin{array}{c}7 \\
50 \\
9.21\end{array}$ & $\begin{array}{c}14 \\
100 \\
14\end{array}$ \\
\hline Positive & $\begin{array}{c}\text { Count } \\
\% \text { within attitude group } \\
\% \text { within knowledge group }\end{array}$ & $\begin{array}{c}17 \\
19.77 \\
70.83\end{array}$ & $\begin{array}{c}69 \\
80.23 \\
90.79\end{array}$ & $\begin{array}{c}56 \\
100 \\
86\end{array}$ \\
\hline Total & $\begin{array}{c}\text { Count } \\
\% \text { within attitude group } \\
\% \text { within knowledge group }\end{array}$ & $\begin{array}{c}24 \\
24 \\
100 \\
\end{array}$ & $\begin{array}{c}76 \\
76 \\
100 \\
\end{array}$ & $\begin{array}{l}100 \\
100 \\
100\end{array}$ \\
\hline
\end{tabular}

$\mathrm{P}$ value $=0.037$, using Fisher's exact test. So, there is significant association between knowledge and attitude of medical students towards organ donation.

$85 \%$ of the students expressed their willingness to work in organ donation campaigne. $15 \%$ were not willing.

\section{Discussion}

In the study, majority said that organs can be donated when alive and were aware that organs can be donated after brain death. There seems to be a decrease in knowledge level regarding age limit for organ donation. Also there is a reduction of legal knowledge among the students regarding organ donation. Most of them answered the siblings are the ideal candidates for organ donation. Only $31 \%$ had sufficient source of information from newspaper, magazines, tv, internet, friends which should be improved. Most of them were aware that they need not pay to be an organ donor. Though most of the students are in favor of the concept of organ donation all those who favor were not willing for organ donation. There is significant association between knowledge and attitude of medical students towards organ donation. Also, more number of the students expressed their willingness to work in organ donation campaigne though they themselves were not willing. At least they could connect those who are willing for organ donation by propagating awareness. There seems to be an increase in knowledge level for third year students compared to first years. Most of them were willing for organ donation. The need for revision of medical curriculum to incorporate more portions on organ donation was also echoed by a clear majority of students. There is no significant relevance for religion and willingness of medical students for organ donation as most of them in all three religion were willing.

In a similar study done by Sahana et al among the medical students of MVJ medical college, Banglore $87.9 \%$ responded that organs can be donated even after death. $68.7 \%$ responded that organs can be donated when alive. $65.2 \%$ responded that organs can be donated after brain death. $63 \%$ were aware that there is a shortage of organs for transplant. $64.5 \%$ were aware of the organ donation act. $57.4 \%$ were of the opinion that 
donated organs could be misused/ abused. $65.2 \%$ were willing to work in organ donation campaign. $65.2 \%$ were willing to donate organs. ${ }^{3}$

In a study done by Adithyan et al among medical students of GMC, Trivandrum majority of the students had adequate knowledge regarding organ donation, but it is not translated into their willingness for donation - both cadaveric and live. ${ }^{4}$

In contrary, in the study done by Nisreen Firoz Ali et al among medical students of Karachi, Pakistan 97.5\% were aware of organ donation but only $44.9 \%$ were willing for organ donation. There was significant association between willingness and knowledge of allowance of organ donation in religion. ${ }^{5}$

In a study conducted by Sucharita et al among undergraduate medical students of Tagore Medical College and Hospital, The mean age of the study participants was 20.34 years, $64.3 \%$ were female students, $90.1 \%$ belonged to Hindu religion. Interestingly, $6.6 \%$ of the participants had a history of organ donation in the family. Ninety-seven percentage of participants ever heard of the term 'organ donation', $90.6 \%$ felt that organ donation should be promoted among whom $74.2 \%$ felt that there is a 'great need' for it. Thirty-two percentage participants responded that they would definitely donate organs after death and $53 \%$ participants responded positively to pledge their organs for donation after death. Reasons mentioned for not pledging were perceived parental and family refusal, fear for personal safety, disapproval of mutilation of body and religion. There was no statistically significant correlation between attitudes, beliefs and demographics.

\section{Conclusion}

From the study it is clear that the knowledge level of the medical students of Kerala is significantly higher compared to other states of India. Also there is no gap between knowledge and attitude among the students. Religion has no much role in attitude of the students as those were considered as individual decision. Those who were not willing were not completely against the concept of organ donation and many of them expressed to work in the campaigne atleast though themselves could not donate. Health professionals play a key role in surpassing this barrier. Hence early training and revision of medical curriculum accordingly is significant. Improving the health care settings as well as awareness in this regard renew the lease of many lives.

\section{Acknowledgement}

Thanking Dr. A K Jayasree, Head of the Department, Dept. of Community Medicine and guide Mrs. Mayamol Pradeep who gave all the guidance and support in completion of the study. Above all thanking God Almighty.

\section{Reference}

1. Sucharitha S T, Sirki R, Dugyala R R, Mullai, Priyadarshini, Kavya et al. Organ donation: awareness, attitudes and beliefs among undergraduate medical students in South India. NJRCM 2013;2(2):83-88

2. National Organ and Tissue Transplant Organization (NOTTO); C2013. Available from: http://www.notto.nic.in/faqs.htm. [Last accessed on 2020 Jan 25].

3. Sahana BN, Sangeeta M. Knowledge, attitude and practices of medical students regarding organ donation. Int J Curr Res Rev 2015;7:74.

4. Adithyan GS, Mariappan M. Factors that determine deceased organ transplantation in India. Indian J Transplant 2017;11:2630.

5. Nisreen Feroz Ali, Amal Qureshi, Basmah Naser Jileni, Nosheen Zehra. Knowledge and ethical perception regarding organ donation among medical students.BMC Medical Ethics 2013,14:38.

6. Thomas Hugh Feeley: College Students' Knowledge, Attitudes, and Behaviors Regarding Organ Donation: An Integrated Review of the Literature Journal of 
Applied Social Psychology Volume 37, Issue 2, pages 243-271, February 2007.

7. M.D Dutra, T.A.S Bonfim, I.S Pereira, et al: Knowledge about transplantation and attitudes toward organ donation: a survey among medical students in Northeast Brazil Transplantation Proceedings Volume 36, Issue 4 , Pages 818-820, May 2004.

8. Watson C J E, Dark J H. Organ transplantation: historical perspective and current practice. British Journal of Anaesthesia 2012;108(S1):129-142.

9. Manojan K K, Raja R, Nelson V, Beevi N, Jose R. Knowledge and attitude towards organ donation in rural Kerala. Academic Medical Journal of India 2014;2(1):25-27.

10. Kowalski AE, Light JA, Ritchie WO, Sasaki TM, Callender CO, Gage F. A new approach for increasing the organ supply. Clin Transplant. Dec 1996;10(6 Pt 2):653657.

11. Aswad S, Souqiyyeh MZ, Huraib S, elShihabi R. Public attitudes toward organ donation in Saudi Arabia. Transplant Proc.Oct 1992;24(5):2056-2058.

12. Juan M, Nicole M, Maria C, Omar E, Esther A. knowledge of and attitudes towards organ donation: A survey of medical students in Puerto Rico. PRHSJ 2013;32(4):187-193.

13. Mekahli D, Liutkus A, Fargue S, Ranchin B, Cochat P. Survey of first-year medical students to assess their knowledge and attitudes toward organ transplantation and donation. Transplant Proc. 2009;41 (2):634-638.
14. McGlade D, Pierscionek B. Can education alter attitudes, behaviour and knowledge about organ donation? A pretest and posttest study. BMJ Open 2013;3:e00396.doi:10.1136/bmjopen2013-003961

15. Mithra P, Ravindra P, Unnikrishnan B, Rekah T, Kanchan T, Kumar N, et al. Perception and attitudes towards organ donation among people seeking healthcare in tertiary care centers of costal South India. Indain J Palliat Care 2013;19:83-87. 